\title{
Effects of Different Salt Concentrations on Quinoa Seedling Quality
}

\author{
Yakup Onur KOCA ${ }^{* 1}$, Selda ÖZMEN², Cansu KÜÇÜK², Nuray ÖKTEM², \\ Ayşe ÖZEROĞLU², Fatma Burcu OKUR²
}

\author{
${ }^{1}$ Adnan Menderes University, Faculty of Agriculture, Department of Field Crop, Aydin, Turkey \\ ${ }^{2}$ Agriculture Engineer, Aydin, Turkey
}

Received: 01 May 2017 - Revised: 16 July 2017 - Accepted: 03 August 2017

\begin{abstract}
The experiment designed a completely randomized experimental design was carried out Adnan Menderes University, Agriculture Faculties greenhouse. Quinoa variety candidate named "Saponinsiz" is used experimental material. The seeds were sowed in plastic pots filled with soil and perlite $(\% 50+\% 50)$ at the greenhouse with six replicates. Five different salt concentrations were determined as 0 (control), $4 \mathrm{ds} \mathrm{m}^{-1}, 8 \mathrm{ds} \mathrm{m}^{-}$ ${ }^{1}, 16 \mathrm{ds} \mathrm{m}^{-1}$ and $30 \mathrm{ds} \mathrm{m}^{-1}$ and were applied with $\mathrm{NaCl}$ solution which was prepared before sowing. Leaf number, leaf length, leaf width, leaf thickness, stem thickness and green biomass weight values were measured when the quinoa plant reached 6 leaf stage. As a result of the study, it was observed that the differences between the salt concentrations in leaf number, leaf length, leaf width and green biomass weight were significant. The maximum leaf length $(11.53 \mathrm{~mm})$ was measured with $8 \mathrm{ds} \mathrm{m}^{-1}$ salt concentration applied plants, whereas the maximum leaf width $(4.99 \mathrm{~mm})$ and green biomass $(1019.5 \mathrm{mg})$ were measured with $4 \mathrm{ds} \mathrm{m}^{-1}$. The control plot only showed the highest values for the leaf number value. These results confirmed that the quinoa plant was facultative halophytic species (salt-resistant). It was determined that $16 \mathrm{ds} \mathrm{m}^{-1}$ dose gave the lowest values in all measurements. And any plant wasn't growing at the $30 \mathrm{ds} \mathrm{m}^{-1}$ applied pots. The values of the experiment measured of $4 \mathrm{ds} \mathrm{m}^{-1}$ pots and 8 $\mathrm{ds}^{-1}$ pots, which is considered the limit values for the field crops, were approximately equal or greater than control pots. Moreover, there was a rapid decline of plant on the $16 \mathrm{ds} \mathrm{m}^{-1}$ values.
\end{abstract}

Keywords: Salinity, Quinoa, Seedling Quality, Green biomass

\section{INTRODUCTION}

Salinity is one of the significant problems commonly observed among irrigated agricultural lands. Nowadays it is showed that salinity soils affect between 20 and $50 \%$ of irrigated arable lands worldwide [1]. Because of natural causes such as Irrigation water, soil structure, regional factors and some human activities, growth retardation and yield loss owing to salinity of soils is a common problem all over the world as most crop plants [2]. One option is the use of halophytic crop species, which can tolerate high levels of soil salinity. Many members of the family Chenopodiaceae are classified as salt tolerant one member of this family, quinoa (Chenopodium quinoa Willd.) is able to grow on salinity soils [3]. Therefore, quinoa plant for new approaches is necessary to cope with the problem.

*Corresponding Author E-mail: yokoca@adu.edu.tr 
The progressive salinization of irrigated land is a major environmental threat for crop production. Therefore, the selection and characterization of salt-resistant species are important to ensure future productivity of the arid and semi-arid agricultural regions [4]. Although quinoa (Chenopodium quinoa Willd) has been cultivated in the South America for at least 7000 years [5], it has garnered much attention around the world in recent years [6], [7]. This interest based on not only its stress tolerance especially salinity soil condition, but also its nutritional quality especially high essential amino acid rates [8]. The main use of quinoa is for people such as cooking, baking, and various products for allergic to gluten and for animals such as feed, green fodder and for regulate plant growth with contains some phytohormones [6]. Besides, it has been considered an oil crop which has proportion of omega- 6 and a notable vitamin E content [9]. Moreover, the seed has an outstanding rich in vitamins $\left(A, B_{2}, C\right)$ and many of minerals such as calcium, magnesium, iron, copper, zinc and lithium, starch and essential fatty acids for human nutrition [10]. For these reasons, the year 2013 was declared "International Year of Quinoa" by the UN Food and Agriculture Organization (FAO) to focus attention on this crop worldwide [11]. Plants develop defense strategies against salt stress based on the activation of the ion transport system, osmotic adjustment and induction of antioxidant enzymes [12]. Seedling period is a critical process during plant life, particularly in the presence of adverse environmental factors such as salinity [13]. The capability of seedling establishment under saline conditions is dependent on cultivar [14]. Even though halophytic crop species are resistant against salinity levels into the soil, it has been shown in several studies that even halophytes are relatively sensitive to salinity during the stages of germination and seedling period $[15,16]$.

The study was conducted in Adnan Menderes University, Agriculture Faculties greenhouse to prove of different salinity concentration effects on quinoa leaf number, leaf length, leaf width, leaf thickness, stem thickness and green biomass weight. Moreover, we planned to determination of quinoa seedling quality onto different salinity levels certainly.

\section{MATERIAL and METHODS}

\subsection{Plant material and salinity treatments}

Quinoa variety candidate named "Saponinsiz" is used experimental material. The seeds of quinoa (Chenopodium quinoa Willd) were obtained from the local producer in Denizli and brought they into Adnan Menderes University, Agriculture Faculties greenhouse in 2016. Prior to experiment they were selected for uniformity of size and twenty-five seeds germinated on filter paper in petri dishes with six replicates for viability test during 7 days. After the period number of seeds germinated on filter paper in petri dishes was determined and the numbers which measured six replicates were Multiplied by 4 to find \% value. 6 replicates were averaged.

The soil used at the study is contents $1.2 \%$ of organic matter, $2978 \mathrm{mg} \mathrm{kg}^{-1} \mathrm{P}_{2} \mathrm{O}_{5}, 101 \mathrm{mg}$ $\mathrm{kg}^{-1}$ exchangeable $\mathrm{K}, 19 \mathrm{mg} \mathrm{kg}^{-1} \mathrm{Ca}$ and 5,6 mg kg${ }^{-1} \mathrm{Na}$. Fe and $\mathrm{Mn}$ were determined as 594 $\mathrm{mg} \mathrm{kg}^{-1}$ and $21 \mathrm{mg} \mathrm{kg}^{-1}$ respectively. 50\% the soil and 50\% perlite mixtures were put in medium pots $(15 \mathrm{~L}$.). Twenty quinoa seeds were sowed the pots. Percent of field capacity calculated randomly selected 3 pots. Afterwards 0 (control), $4 \mathrm{ds} \mathrm{m}^{-1}, 8 \mathrm{ds} \mathrm{m}^{-1}, 16 \mathrm{ds} \mathrm{m}^{-1}$ and $30 \mathrm{ds} \mathrm{m}^{-1}$ $\mathrm{NACl}$ concentration were threatened with calculated water. Infiltration cases were placed under the pots against the possibility of infiltration. These proses were repeated again to 6 pots each salt concentrations. Thus, the study was conducted with six replicates. Leaf number, leaf length, leaf width, leaf thickness, stem thickness and green biomass weight values were measured 50 days after sowing (45 days after the germination) of quinoa when the seedlings reached 6 leaf stage. 
The traits studied in this research were determined in the following ways: Leaf number: 5 plants randomly selected from each pot and were separated from others. All leaves of the plants were counted. The average was taken to obtain the replicate value of salt concentrations.

Leaf length: Leaf length was measured all leaves of the plants from the tip to bottom of the leaf blade by electronic compass. The average was taken to obtain the replicate value of salt concentrations.

Leaf width: Leaf width was measured all leaves of the plants at the widest part of the leaf by electronic compass. And the average was taken to obtain the replicate value of salt concentrations.

Leaf thickness: Leaf thickness were measured all leaves of the plants by Electronic compass. And the average was taken to obtain the replicate value of salt concentrations.

Stem thickness: Stem thickness were measured all stems of the plants by Electronic compass. And the average was taken to obtain the replicate value of salt concentrations.

Green Biomass: Randomly selected 5 plants from each pot were weighed. The weight of this named fresh, or "green" biomass $[17,18]$. The average was taken to obtain the replicate value of salt concentrations.

\section{Statistical Analysis}

Data of growth and seedling quality were analyzed by TARIST [19]. Means were compared between treatments by LSD (least significant difference) at the 0.05 confidence level.

\section{RESULTS and DISCUSSIONS}

The calculated mean squares with variance analyses for salt concentration levels are presented in Table 1.

Table 1. The calculated mean squares with variance analyses for all components measured of quinoa seed

\begin{tabular}{lcccccc}
\hline Variance Source & $\begin{array}{c}\text { Leaf } \\
\text { Length }\end{array}$ & $\begin{array}{c}\text { Leaf } \\
\text { width }\end{array}$ & $\begin{array}{c}\text { Leaf } \\
\text { thickness }\end{array}$ & $\begin{array}{c}\text { Leaf } \\
\text { number }\end{array}$ & $\begin{array}{c}\text { Stem } \\
\text { thickness }\end{array}$ & $\begin{array}{c}\text { Green } \\
\text { biomass }\end{array}$ \\
\hline Salt concentration levels & $12,95^{*}$ & $7,52^{* *}$ & $0,03 \mathrm{~ns}$ & $7,49 * *$ & $0,03 \mathrm{~ns}$ & $444867,38^{* *}$ \\
Error & 2,38 & 0,26 & 0,01 & 0,91 & 0,01 & 19518,50 \\
\hline
\end{tabular}

The effect of different salt concentrations during germination and seedling period on Leaf number, leaf length, leaf width, leaf thickness, stem thickness and green biomass values were determined. Salt concentration level was found to be significant in some parameters measured such as leaf number, leaf length, leaf width and green biomass, but leaf thickness and stem thickness values were found to be no significant.

Table 2 were edited some seedling quality characteristics as leaf number, leaf length, leaf width, leaf thickness, stem thickness and green biomass values under different salt concentrations. $30 \mathrm{ds} \mathrm{m}^{-1}$ pots were ignored. Because germination of the quinoa seeds in the pots were realized either no one exited or few were exited than died for over salt level. Quinoa optimal plant growth was obtained between $10 \mathrm{ds} \mathrm{m}^{-1}$ and $20 \mathrm{ds} \mathrm{m}^{-1} \mathrm{NaCl}$. Only some variety of quinoa such as Titicaca observed a significant inhibitory effect on seed germination for concentrations higher than $40 \mathrm{ds} \mathrm{m}^{-1} \mathrm{NaCl}$. Therefore, this is said that quinoa plant was tolerated under moderately saline conditions $\left(10-20 \mathrm{ds} \mathrm{m}^{-1}\right)$ [6]. 
Leaf area is an important trait for the yield, because biomass was dictated the amount of light which can be absorbed. As the one of the main criteria that determine the leaf area, maximum leaf length was obtained from $8 \mathrm{ds} \mathrm{m}^{-1}(11.52 \mathrm{~cm})$ salt concentration. The average of $4 \mathrm{ds} \mathrm{m}^{-1}(11.15 \mathrm{~cm})$ were followed. Minimum average of leaf length value was given from $16 \mathrm{ds} \mathrm{m}^{-1}(8,46 \mathrm{~cm})$. As another of the main criteria that determine the leaf area, maximum leaf width was obtained from $4 \mathrm{ds} \mathrm{m}^{-1}(4,99 \mathrm{~cm})$ salt concentration. The average of $8 \mathrm{ds} \mathrm{m}^{-1}(4,82$ $\mathrm{cm})$ were followed. Minimum average of leaf width value was given from $16 \mathrm{ds} \mathrm{m}^{-1}(2,54 \mathrm{~cm})$. When measured leaf size values were evaluated, $16 \mathrm{ds} \mathrm{m}^{-1}$ salt concentration caused a decrease of both leaf length and leaf width approximately $37 \%$ and $49 \%$ respectively as compared with maximum leaf length $\left(8 \mathrm{ds} \mathrm{m}^{-1}\right)$ and maximum leaf width $\left(4 \mathrm{ds} \mathrm{m}^{-1}\right)$. The results of these two measurements, we can say that quinoa is salt-resistant plant up to $8 \mathrm{ds} \mathrm{m}^{-1}$ level and the yield could not be significantly affected to these salt levels due to the significant correlations between leaf area and dry matter of quinoa [20].

Leaf thickening is considered as a mechanism to increase the water retention by mesophyll tissues in order to counteract salt toxicity [21]. Because leaf thickness was observed the relationship between stomatal conductance, mesophyll conductance, and mesophyll thickness [22]. Maximum leaf thickness was obtained from $16 \mathrm{ds} \mathrm{m}^{-1}(0,58 \mathrm{~cm})$ salt concentration. The average of $8 \mathrm{ds} \mathrm{m}^{-1}(0,57 \mathrm{~cm})$ were followed. The control group was given minimum average of leaf thickness value $(0,42 \mathrm{~cm})$. Our results are consistent with the other investigations $[16,23]$. The leaf thickness significantly increased as the percentage of salinity increased. Increasing of leaf thickness can be referred to the water storage in the hypodermal tissue, which affected of leaf thickness values especially under high salinity. Therefore, salinity stimulates the increasing of leaf thickness and fresh weight owing to water storage perhaps contributes to decreased toxicity of salinity [24]. Leaf thickness were considerably higher in the leaves of high salt treated plants $[25,26]$. Increased leaf thickness has been reported as a successful trait for plant species growing under saline conditions. There was a positive correlation between the stomatal conductance and mesophyll conductance that affect diffusion of $\mathrm{CO} 2$ and rate of photosynthesis inside leaf cells. Thus, mesophyll thickness was inversely correlated with mesophyll conductance and leaf porosity. Further reduction in $\mathrm{K}+$ content under the condition of increased salinity may damage the photosynthetic machinery [27], [28].

Contrary to leaf thickness, stem thickness decreased during the increase in salinity doses. Maximum stem thickness was obtained from control $(0,76 \mathrm{~cm})$ salt concentration. The average of $4 \mathrm{ds} \mathrm{m}-1(0,73 \mathrm{~cm})$ were followed. Minimum average of stem thickness value was given from $16 \mathrm{ds} \mathrm{m-1}(0,61 \mathrm{~cm})$.

Leaf number can be used to characterize plant assimilation capacity [29]. Maximum leaf number was obtained from control parcels $(6,00)$ salt concentration. The average of $4 \mathrm{ds} m-1$ $(5,17)$ and $8 \mathrm{ds} \mathrm{m-1}(5,00)$ were followed. These three levels different from the other level $(16$ ds m-1) statistically. Minimum average of leaf number value was given from $16 \mathrm{ds}$ m-1 $(3,33)$. High salt concentration (16 ds m-1) caused a decrease of leaf number approximately $45 \%$ as compared with control parcels which obtained maximum leaf number average. The leaf number increased in the control and decreased as $\mathrm{NaCl}$ dose was increased [30, 31].

There are many studies which have been determined to correlation between biomass [32], [33] and grain yield [20]. Maximum green biomass was obtained from $4 \mathrm{ds} \mathrm{m-1}(1019,50 \mathrm{mg})$ salt concentration. The average of $8 \mathrm{ds} \mathrm{m}-1(852,17 \mathrm{mg})$ and control $(727,67 \mathrm{mg})$ were followed. Minimum average of green biomass value was given from $16 \mathrm{ds}$ m-1 $(377,17 \mathrm{mg})$. Biomass reduction into $16 \mathrm{ds} \mathrm{m}-1$ level was determined as nearly by half of control level. Moreover 16 ds m-1 salt concentration caused a decrease of biomass approximately $73 \%$ as compared with biomass of $4 \mathrm{ds} \mathrm{m}-1$ given maximum green biomass. The really depressive effects of salinity on seedling was showed into the $16 \mathrm{ds} \mathrm{m}-1$ salinity level. Thus, it is expected 
that the quinoa will decrease in biomass up to $16 \mathrm{ds} \mathrm{m-1.} \mathrm{Quinoa} \mathrm{has} \mathrm{demonstrated} \mathrm{the} \mathrm{ability}$ to accumulate salt ions in its tissues in order to control and adjust leaf water potential. This enables the plants to maintain cell turgor and limit transpiration under saline conditions, avoiding physiological damage [34]. But there were very different results among to quinoa cultivars. Nevertheless, some varieties can withstand very high salt doses, generally average of salt level $11 \mathrm{ds}$ m-1 for an increase in both leaf area and biomass of plants grown at compared to those grown at control level.

Table 2. Trypan Blue Assay results.

\begin{tabular}{lcccccc}
\hline SCL & LL $(\mathrm{cm})$ & LW $(\mathrm{cm})$ & LT $(\mathrm{cm})$ & ST $(\mathrm{cm})$ & LN & $\begin{array}{c}\text { GB } \\
(\mathrm{mg})\end{array}$ \\
\hline Control & $9,30 \mathrm{bc}$ & $4,32 \mathrm{~b}$ & 0,42 & 0,76 & $6,00 \mathrm{a}$ & $727,67 \mathrm{~b}$ \\
$4 \mathrm{dsm}$ & $11,15 \mathrm{ab}$ & $4,99 \mathrm{a}$ & 0,51 & 0,73 & $5,17 \mathrm{a}$ & $1019,50 \mathrm{a}$ \\
$8 \mathrm{dsm}$ & $11,52 \mathrm{a}$ & $4,82 \mathrm{ab}$ & 0,57 & 0,72 & $5,00 \mathrm{a}$ & $852,17 \mathrm{ab}$ \\
$16 \mathrm{dsm}$ & $8,46 \mathrm{c}$ & $2,54 \mathrm{c}$ & 0,58 & 0,61 & $3,33 \mathrm{~b}$ & $377,17 \mathrm{c}$ \\
LSD & 1,86 & 0,61 & ns & Ns & 1,15 & 168,37 \\
\hline
\end{tabular}

SCL: salt concentration levels, LL: leaf length, LW: leaf width, LT: leaf thickness, ST: stem thickness, GB: green biomass

\section{CONCLUSIONS}

Many regions of the world especially in arid and semi-arid regions are affected by salt problems. Few crops can be grown in these marginal areas, as plants grown on saline soils must be species tolerant to salinity, such as quinoa because of both stress tolerances to salinity soil condition and its nutritional quality especially high essential amino acid rates. Maximum values of leaf length, leaf width and green biomass of the experiment were measured $4 \mathrm{ds} \mathrm{m}^{-1}$ pots and $8 \mathrm{ds} \mathrm{m}^{-1}$ pots, which is considered the limit values for the field crops. We can say that quinoa is salt-resistant plant up to $8 \mathrm{ds} \mathrm{m}^{-1}$ level. Moreover, there was a rapid decline of plant on the $16 \mathrm{ds} \mathrm{m}^{-1}$ which minimum values were measured of all the traits. Therefore, new salt doses between $8 \mathrm{ds} \mathrm{m}^{-1}$ and $16 \mathrm{ds} \mathrm{m}^{-1}\left(10 \mathrm{ds} \mathrm{m}^{-1}, 12 \mathrm{ds} \mathrm{m}^{-1}\right.$ and $\left.14 \mathrm{ds} \mathrm{m}^{-1}\right)$ may be determined because of be able to see that the certain limit of salt concentration which is quinoa seedling resistant.

\section{Conflict of Interests}

Authors declare that there is no conflict of interests.

\section{REFERENCES}

[1]. Pitman, M. G., \& Läuchli, A. (2002). Global impact of salinity and agricultural ecosystems. Salinity: environment-plants-molecules, 3, 20.

[2]. Munns, R., \& Tester, M. (2008). Mechanisms of salinity tolerance. Annu. Rev. Plant Biol., 59, 651-681.

[3]. Wilson, C., Read, J. J., \& Abo-Kassem, E. (2002). Effect of mixed-salt salinity on growth and ion relations of a quinoa and a wheat variety. Journal of Plant Nutrition, 25(12), 26892704.

[4]. Ruiz-Carrasco, K., Antognoni, F., Coulibaly, A. K., Lizardi, S., Covarrubias, A., Martínez, E. A., \& Zurita-Silva, A. (2011). Variation in salinity tolerance of four lowland genotypes of quinoa (Chenopodium quinoa Willd.) as assessed by growth, physiological traits, and sodium transporter gene expression. Plant Physiology and Biochemistry, 49(11), 13331341.

[5]. Rindos, D. (1992). The Origins of Agriculture. An International Perspective, Smithsonian Institution Press, Washington, London, pp. 173-205. 
[6]. Jacobsen, S. E., Mujica, A., \& Jensen, C. R. (2003). The resistance of quinoa (Chenopodium quinoa Willd) to adverse abiotic factors. Food Reviews International, 19(12), 99-109.

[7]. Jacobsen, S.-E., Mujica, A. (2001). Avances en el conocimiento de resistencia a factores abio'ticos adversos en la quinua (Chenopodium quinoa Willd.). Memorias Primer Taller Internacional de la Quinua., Lima, Peru.

[8]. Repo-Carrasco, R., Espinoza, C., \& Jacobsen, S. E. (2003). Nutritional value and use of the Andean crops quinoa (Chenopodium quinoa) and kañiwa (Chenopodium pallidicaule). Food reviews international, 19(1-2), 179-189.

[9]. James, J. J., Alder, N. N., Mühling, K. H., Läuchli, A. E., Shackel, K. A., Donovan, L. A., \& Richards, J. H. (2005). High apoplastic solute concentrations in leaves alter water relations of the halophytic shrub, Sarcobatus vermiculatus. Journal of Experimental Botany, 57(1), 139-147.

[10]. Kozioł, M. J. (1992). Chemical composition and nutritional evaluation of quinoa (Chenopodium quinoa Willd.). Journal of Food Composition and Analysis, 5(1), 35-68.

[11]. Small, E. (2013). Quinoa: is the United Nations' featured crop of 2013 bad for biodiversity. Biodiversity, 14(3), 169-79.

[12]. Flagella, Z., Trono, D., Pompa, M., Di Fonzo, N., \& Pastore, D. (2006). Seawater stress applied at germination affects mitochondrial function in durum wheat (Triticum durum) early seedlings. Functional Plant Biology, 33(4), 357-366.

[13]. Bohnert, H. J., Nelson, D. E., \& Jensen, R. G. (1995). Adaptations to environmental stresses. The plant cell, 7(7), 1099.

[14]. Hariadi, Y., Marandon, K., Tian, Y., Jacobsen, S. E., \& Shabala, S. (2010). Ionic and osmotic relations in quinoa (Chenopodium quinoa Willd.) plants grown at various salinity levels. Journal of experimental botany, 62(1), 185-193.

[15]. Ungar, I. A. (1996). Effect of salinity on seed germination, growth, and ion accumulation of Atriplex patula (Chenopodiaceae). American Journal of Botany, 604-607.

[16]. Debez, A., Saadaoui, D., Ramani, B., Ouerghi, Z., Koyro, H. W., Huchzermeyer, B., \& Abdelly, C. (2006). Leaf H+-ATPase activity and photosynthetic capacity of Cakile maritima under increasing salinity. Environmental and Experimental Botany, 57(3), 285295.

[17]. Picard, N., Saint-André, L., \& Henry, M. (2012). Manual for building tree volume and biomass allometric equations: from field measurement to prediction. Food and Agriculture Organization of the United Nations, Rome. 215 p.

[18]. DeYoung, C. (2014). Biomass estimation using the component ratio method for white oak (Doctoral dissertation, Virginia Tech)., USA. P: 63.

[19]. Açıkgöz, N., İlker, E., \& Gökçöl, A. (2004). Biyolojik araştırmaların bilgisayarda değerlendirilmeleri. Ege Üniversitesi Tohum Teknolojisi Uygulama ve Araştırma Merkezi, Yayın, (2)..

[20]. Jacobsen, S. E., Jensen, C. R., \& Pedersen, H. (2005). Use of the relative vegetation index for growth estimation in quinoa (Chenopodium quinoa Willd). J Food Agric Environ, 3, 169-175.

[21]. Naz, N., Rafique, T., Hameed, M., Ashraf, M., Batool, R., \& Fatima, S. (2014). Morphoanatomical and physiological attributes for salt tolerance in sewan grass (Lasiurus scindicus Henr.) from Cholistan Desert, Pakistan. Acta physiologiae plantarum, 36(11), 2959-2974. 
[22]. Loreto, F., Harley, P. C., Di Marco, G., \& Sharkey, T. D. (1992). Estimation of mesophyll conductance to CO 2 flux by three different methods. Plant physiology, 98(4), 1437-1443.

[23]. Çavuşoğlu, K., Kılıç, S., \& Kabar, K. (2007). Some morphological and anatomical observations during alleviation of salinity $(\mathrm{NaCI})$ stress on seed germination and seedling growth of barley by polyamines. Acta Physiologiae Plantarum, 29(6), 551-557.

[24]. Farshidi, M., Abdolzadeh, A., \& Sadeghipour, H. R. (2012). Silicon nutrition alleviates physiological disorders imposed by salinity in hydroponically grown canola (Brassica napus L.) plants. Acta physiologiae plantarum, 34(5), 1779-1788.

[25]. Parida, A.K., Veerabathini, S.K., Kumari A., \& Agarwal P.K. (2016). Physiological, Anatomical and Metabolic Implications of Salt Tolerance in the Halophyte Salvadora persica under Hydroponic Culture Condition. Frontiers in Plant Science, 7, 1-11.

[26]. Taneenah, A., Nulit, R., Yusof, U.K., \& Janaydeh, M. (2015). Tolerance of Molokhia (Corchorus olitorius L.) Seed with Dead Sea Water, Sea Water, and NaCl: Germination and Anatomical Approach. Advances in Environmental Biology, 9(27), 106-116.

[27]. Chow, W.S., Ball, M.C., \& Anderson, J.M. (1990). Growth and photosynthetic responses of spinach to salinity: implications of $\mathrm{K}+$ nutrition for salt tolerance. Functional Plant Biology, 17(5), 563-578.

[28]. Werner, A., \& Stelzer, R. (1990). Physiological responses of the mangrove Rhizophora mangle grown in the absence and presence of NaCl. Plant, Cell \& Environment, 13(3), 243-255.

[29]. Hoogenboom, G., Peterson, C.M., \& Huck, M.G. (1987). Shoot growth rate of soybean as affected by drought stress. Agron. J., 79, 598-607.

[30]. Murillo-Amador, B., Nieto-Garibay, A., Troyo-Diéguez, E., García-Hernández, J.L., Hernández-Montiel, L., \& Valdez-Cepeda, R.D. (2015). Moderate Salt Stress on the Physiological and Morphometric Traits of Aloe Vera L. Botanical Sciences, 93(3), 639648.

[31]. Moghbeli, E., Fathollahi, S., Salari, H., Ahmadi, G., Saliqehdar, F., Safari, A. \& Grouh, M.S.H. (2012). Effects of salinity stress on growth and yield of Aloe vera L. Journal of Medicinal Plants Research, 6, 3272-3277.

[32]. Lawrence, P.R., Gérard, B., Moreau, C., Lhériteau, F., \& Bürkert, A. (2000). Design and testing of a global positioning system-based radiometer for precision mapping of pearl millet total dry matter in the Sahel. Agronomy Journal, 92, 1086-1095.

[33]. Vargas, L.A., Andersen, M.N., Jensen, C.R., \& Jørgensen, U. (2002). Estimation of leaf area index, light interception and biomass accumulation of Miscanthus sinensis "Goliath" from radiation measurements. Biomass and Bioenergy, 22, 1-14.

[34]. Gómez-Pando, L. R., Álvarez-Castro, R., \& Eguiluz-de la Barra, A. (2010). Effect of salt stress on Peruvian germplasm of Chenopodium quinoa Willd.: a promising crop. Journal of Agronomy and Crop Science, 196(5), 391-396. 